\title{
RENCANA BISNIS (BUSINESS PLAN) JASA CONTENT CREATOR
}

\author{
Abdi Ramadhan \\ Program Studi Magister Manajemen Universitas Tarumanagara \\ abdiramadhn@gmail.com \\ Eddy Supriyatna \\ Program Studi Magister Manajemen Universitas Tarumanagara
}

Masuk : 07-12-2019, revisi : 20-12-2019 diterima untuk diterbitkan : 20-12-2019

\begin{abstract}
Business Planning Content Creator Services" is a business plan that offers services in the creative industries. With the rapid development of social media in this digital age, we can see a potential opportunity to plan a content creator service business, which includes several service components, namely photography, videography, design, copywriting, social media handling, and creative ideas for projects. This business plan aims to create a new business plan in the creative industries engaged in services and create opportunities to be able to generate profitable profits. Based on the results of the analysis and discussion, it can be concluded that this business is feasible to be realized on the basis of considerations, among others, because the market potential of the content creator services business increases with the increasing use of social media in Indonesia. This business financial planning also shows that this business will provide profit and deserve to be realized. Financial analysis which consists of Payback Period and Break Event Point (BEP) requires a fairly short estimated time of 2 years 3 months, the Net Present Value (NPV) value of Rp. 291,120,221.5, - this shows that this investment can be profitable and profitable, and the Internal Rate of Return (IRR) of $81 \%$ means higher than the interest rate.
\end{abstract}

Abstrak : "Perencanaan Bisnis Jasa Content Creator" adalah rencana bisnis usaha yang menawarkan jasa di bidang industri kreatif. Dengan semakin pesatnya perkembangan media sosial di era digital ini, maka kita dapat melihat suatu peluang yang cukup potensial untuk merencanakan bisnis jasa content creator, yang mencakup beberapa komponen jasa yaitu photography, videography, design, copywriting, social media handling, dan creative idea for project. Perencanaan bisnis ini bertujuan untuk membuat suatu rencana bisnis baru pada industri kreatif yang bergerak di bidang jasa serta menciptakan kesempatan untuk dapat menghasilkan profit yang menguntungkan. Berdasarkan hasil analisa dan pembahasan, maka dapat disimpulkan bahwa bisnis ini layak direalisasikan dengan dasar pertimbangan antara lain karena potensi pasar bisnis jasa content creator meningkat seiring meningkatnya penggunaan media sosial di Indonesia. Perencanaan keuangan bisnis ini juga menunjukan bahwa bisnis ini akan memberikan profit dan layak untuk direalisasikan. Analisa keuangan yang terdiri dari Payback Period dan akan Break Event Point (BEP) membutuhkan perkiraan waktu yang cukup singkat yaitu 2 tahun 3 bulan, nilai Net Present Value (NPV) dengan nilai Rp. 291,120,221.5,hal ini menunjukan investasi ini dapat menghasilkan dan menguntungkan, serta nilai Internal Rate of Return (IRR) sebesar $81 \%$ yang berarti lebih tinggi dari nilai suku bunga.

Keywords : Business Plan, Content Creator, Payback Period, Break Even Point, Net Present Value, Internal Rate of Return 


\section{PENDAHULUAN}

Perkembangan teknologi digital terutama pada media sosial di Indonesia semakin berkembang pesat, banyak sekali hal-hal yang dapat menguntungkan di media sosial, bahkan menjadi sebuah bisnis yang cukup menjanjikan. Content creator contohnya, ketika media sosial semakin dikenal oleh banyak orang dan semenjak kita memasuki jaman era digital seperti sekarang ini. Di dalam dunia usaha, bisnis content creator dikategorikan ke dalam ekonomi kreatif. Ekonomi kreatif dapat didefinisikan sebagai Industri kreatif yang mengandalkan talenta, keterampilan, dan kreatifitas yang merupakan elemen dasar setiap individu. Unsur utama industri kreatif bermula dari pemanfaatan ide kreatif, keterampilan dan bakat yang terus di kembangkan demi menciptakan kesejahteraan dan lapangan pekerjaan dengan memberdayakan kreatifitas yang telah dibangun dan di terapkan. Di Indonesia sendiri industri ekonomi kreatif berkontribusi terhadap perekonomian Indonesia sektor ekonomi kreatif terbukti menjadi sumber dan kekuatan ekonomi baru bagi Indonesia, apalagi di tengah melambatnya harga komoditas dan bahan mentah secara global, sektor ekonomi kreatif mampu memberikan sumbangan yang positif bagi perekonomian Indonesia. Tugas ekonomi kreatif adalah memberikan nilai tambah, sehingga dapat menghasilkan produk yang bernilai tinggi dan berkontribusi besar pada perekonomian. Menurut Penelitian yang dilakukan We Are Social, perusahaan media asal Inggris yang bekerja sama dengan Hootsuite, rata-rata orang Indonesia menghabiskan tiga jam 23 menit dalam sehari untuk mengakses media sosial. Dari laporan berjudul "Essential Insights Into Internet, Social Media, Mobile, and E-Commerce Use Around The World" yang diterbitkan tanggal 30 Januari 2018, dari total populasi Indonesia sebanyak 265,4 juta jiwa, pengguna aktif media sosialnya mencapai 130 juta dengan penetrasi $49 \%$, Sebanyak 120 juta orang Indonesia menggunakan perangkat mobile, seperti smartphone atau tablet untuk mengakses media sosial, dengan penetrasi $45 \%$. Dalam sepekan, aktivitas online di media sosial melalui smartphone mencapai 37\%. Dilihat dari perkembangan bisnis ekonomi kreatif, content creator menunjukkan pertumbuhan yang pesat, Dalam bidang ini jasa content creator di tuntut untuk dapat memberikan suatu ide kreatif dan inovatif kepada konsumen, karya yang dihasilkan tentunya mengikuti tren digitalisasi media. Sehingga karya yang dihasilkan dapat membantu dalam kegiatan promosi dari suatu brand yang menggunakan jasa tersebut dan pada akhirnya bisnis ini dapat menjawab semua keinginan konsumen dalam penanganan campaign produk mereka di media sosial. Dari beberapa hal ini, dapat dikatakan bisnis untuk menjadi seorang content creator sangat menjanjikan, selain itu hal ini sudah menjadi kebutuhan bagi suatu brand atau bahkan orang - orang yang memiliki power di media sosial, contohnya seperti selebgram, youtuber, influencer atau bahkan artis. Oleh karena itu penulis merasa sangat tertarik untuk melakukan pembuatan tesis ini yang berhubungan dengan rencana bisnis usaha jasa dibidang industri kreatif, dengan judul "RENCANA BISNIS (BUSINESS PLAN) JASA CONTENT CREATOR".

\section{Tujuan}

Penulisan tesis perencanaan bisnis ini bertujuan untuk :

1. Membuat suatu rencana bisnis baru bidang jasa pada industri kreatif

2. Membangun semangat kreatifitas masyarakat di Indonesia

3. Membuka lapangan kerja untuk meningkatkan taraf hidup masyarakat

\section{RENCANA BISNIS}

\section{STP (Segmenting, Targeting, Positioning)}

Menurut Kotler dan Amstrong (2018 : 74) segmentasi pasar yaitu membagi pasar menjadi kelompok pembeli yang berbeda yang memiliki kebutuhan, karakteristik, atau perilaku berbeda dan yang mungkin memerlukan strategi pemasaran atau campuran yangberbeda. Segmentasi itu sendiri terbagi menjadi 4 yaitu ada Segmentasi Geografik, Demografik, Psikografik dan Faktor Perilaku, berikut ini adalah penjabaran dari penerapan segmentasi pada 90's Visual : 


\section{Segmenting}

\section{a. Segmentasi Geografik}

Segmen geografik yang akan dijangkau oleh 90's Visual untuk saat ini adalah di daerah Tangerang Kota, Tangerang Selatan hingga Jakarta, tepatnya daerah Bumi Serpong Damai (BSD), Bintaro, Senayan, Panglima Polim, Blok M, dan Kemang. Karena daerah tersebut merupakan tempat berkumpulnya para influencer dan selebgram, banyak company bidang kuliner, fashion atau clothing seperti distro distro dan perusahaan - perusahaan start up digital. Dengan begitu dapat terlihat peluang yang cukup potensial untuk menjalin hubungan kerjasama dengan mereka yang memiliki power di media sosial.

\section{b. Segmentasi Demografik}

Segmen Demografik yang akan di jangkau oleh 90's Visual saat ini yaitu :

1. Remaja Akhir 19 - 25 tahun.

2. Dewasa Awal 26 - 35 tahun.

3. Dewasa Akhir 36 - 45 tahun.

\section{c. Segmentasi Psikografik}

Segmen yang akan dijangkau oleh 90's Visual yaitu mulai dari anak - anak remaja yang sedang mendapatkan tugas kuliah untuk membuka suatu bisnis dan membutuhkan jasa content creation pada media sosial yang akan digunakan, dan orang dewasa awal yang baru membuka usaha dan kurang memahami bagaimana membuat konsep pembuatan konten pada media sosial bisa berupa foto konten, video, ataupun pembuatan desain, dan motion graphic, bahkan menangani media sosial dari bisnis tersebut atau yang biasa kita sebut social media handling. Dengan tujuan untuk promosi dan membuat ide kreatif untuk menarik konsumen terhadap produk atau jasa yang ditawarkan.

\section{Targeting}

Menurut Kotler dan Amstrong (2018 : 75) Targeting merupakan suatu kegiatan mengevaluasi setiap daya tarik segmen pasar dan memilih satu atau lebih segmen untuk melayani. Dan penerapan targeting 90's Visual bukan hanya pembuatan konten di media sosial untuk personal ataupun bisnis - bisnis kuliner, clothing dan fashion, tetapi 90's

Visual juga membuka kerjasama dalam pekerjaan Content Creation untuk Event Organizer (EO), dengan menerapkan ide kreatif yang telah dipikirkan secara terkonsep dan matang, ke dalam platform media sosial yang akan digunakan untuk show off kepada masyarakat akan event atau acara yang kedepannya akan dilaksanakan dalam waktu yang sudah ditentukan oleh pihak Event Organizer (EO) secara visual.

\section{Positioning}

Menurut Kotler dan Amstrong (2018 : 75) Positioning itu sendiri berfungsi untuk mengatur suatu produk untuk menempati tempat yang jelas, khas, dan diinginkan relatif terhadap produk yang bersaing dibenak konsumen. Dalam hal ini 90's Visual melakukan positioning terhadap seluruh kegiatan jasa pembuatan konten seperti, konten untuk usaha bisnis kuliner, usaha bisnis clothing, fashion brand, dan bertanggung jawab atas karya yang telah di kerjakan, dengan tujuan untuk mendapatkan perhatian dibenak konsumen.

\section{Marketing Mix 4P (Product, Price, Place, Promotion)}

\section{Product}

90's Visual merupakan sebuah company yang menawarkan jasa pembuatan konten kreatif khususnya pada media sosial. Produk yang dihasilkan yaitu :
a. Foto
b. Video
c. Social Media Handling
d. Desain 


\section{Price}

Beberapa strategi penetapan harga yang diterapkan :

a. Competition oriented pricing yang merupakan cara penetapan harga yang kami gunakan yang berdasarkan kepada harga - harga yang ditetapkan oleh pesaing atau kompetitor kami.

b. Demand oriented pricing yang merupakan cara penetapan harga yang kami lakukan dengan mempertimbangkan keadaan permintaan, keadaan pasar dan keinginan konsumen.

Berdasarkan kepada demand, misalnya harga akan naik apabila demand sangat kuat dan harga akan turun apabila demand melemah.

\section{Place}

Rencana tempat pelayanan jasa 90's Visual yaitu melalui :

a. Media Sosial dan platform yang dimiliki 90's Visual (Instagram, facebook, twitter, website, Behance)

b. Event - event kreatif yang akan diikuti oleh 90's Visual

c. Rumah di berlokasi di Perumahan Buana Gardenia, Jalan Buana Asri II, Blok F3/No.5, Tangerang dengan konsep Production House.

\section{Promotion}
a. Advertising
b. Podcast
c. Video Teaser

\section{Kebutuhan Investasi dan Modal Kerja}

Perencanaan keuangan bertujuan untuk memberikan gambaran seberapa besar potensi keuntungan dari suatu bisnis dan memantau kinerja perusahaan dari sisi keuangan yang digunakan dalam mengambil keputusan berkaitan dengan kebijakan finansial maupun operasional perusahaan. Total modal awal yang diperlukan untuk memulai bisnis ini adalah Rp.373,100,000.-

Tabel 1

Biaya Investasi Awal

\begin{tabular}{|c|l|r|}
\hline No & \multicolumn{1}{|c|}{ Keterangan } & \multicolumn{1}{c|}{ Biaya } \\
\hline 1 & Fixed Assets & $335,100,000$ \\
\hline 2 & Biaya Awal Lainnya & $13,000,000$ \\
\hline & Total Biaya Investasi Awal & $\mathbf{3 4 8 , 1 0 0 , 0 0 0}$ \\
\hline
\end{tabular}

Tabel 2

Sewa Bangunan

\begin{tabular}{|c|l|r|c|}
\hline No & \multicolumn{1}{|c|}{ Bangunan } & Harga Sewa & Jumlah \\
\hline 1 & Rumah Dua Lantai & $25,000,000$ & 1 \\
\hline & Total & $\mathbf{2 5 , 0 0 0 , 0 0 0}$ & \\
\hline
\end{tabular}

\section{Payback Period (PP)}

Payback Period merupakan periode atau jumlah tahun yang diperlukan untuk mengembalikan nilai investasi yang telah dikeluarkan. Payback Period dalam bahasa Indonesia dapat disebut juga dengan Periode Pengembalian Modal. Para pengusaha atau investor sering menggunakan Payback Period sebagai penentu seseorang dalam mengambil keputusan ingin berbisnis atau akan menginvestasikan uangnya ke suatu proyek atau tidak. 
Tabel 3

Payback Period (PP)

\begin{tabular}{|c|c|}
\hline Tahun & Laba Rugi \\
\hline 2021 & $-72,518,750$ \\
\hline 2022 & $-1,243,125$ \\
\hline 2023 & $78,692,875$ \\
\hline 2024 & $159,667,163$ \\
\hline 2025 & $243,952,004$ \\
\hline Nilai Payback Period & 3+(Initial Investment : Cash Flow) $\mathbf{x}$ 1 tahun = 2,03 (2 tahun 3 bulan) \\
\hline
\end{tabular}

Dari keterangan tabel diatas (tabel 3) dijelaskan bahwa nilai payback period atau perusahaan akan Break Even Point dalam waktu 2 tahun 3 bulan.

\section{NPV (Net Present Value)}

Merupakan jumlah dari kenaikan keuntungan yang didapatkan oleh suatu perusahaan atau apabila kita berinvestasi. Dan untuk dapat menghitung nilainya, kita terlebih dahulu menentukan suku bunga (interest rate) yang kita anggap bisa dipercaya dan sesuai standar, sesuai dengan tingkat pengembalian yang didapat jika dananya kita tanamkan ditabungan atau deposito. Pada bisnis ini asumsinya menggunakan suku bunga sebesar $7 \%$.

Tabel 4

NPV (Net Present Value)

\begin{tabular}{|c|c|}
\hline Tahun & Laba Rugi \\
\hline 2021 & $-72,518,750.0$ \\
\hline 2022 & $-1,243,125.0$ \\
\hline 2023 & $78,692,875.0$ \\
\hline 2024 & $159,667,162.5$ \\
\hline 2025 & $243,952,003.8$ \\
\hline Interest Rate & $7 \%$ \\
\hline NPV & $\mathbf{2 9 1 , 1 2 0 , 2 2 1 . 5}$ \\
\hline
\end{tabular}

\section{IRR (Internal Rate of Return)}

Internal Rate of Return disingkat IRR yang merupakan indikator tingkat efisiensi dari suatu bisnis dan investasi. IRR juga merupakan suatu nilai petunjuk yang identik dengan seberapa besar suku bunga yang dapat dihasilkan oleh bisnis atau investasi tersebut dibandingkan dengan suku bunga bank yang berlaku umum, apabila tingkat yang dihasilkan lebih besar maka bisnis atau investasi tersebut dianggap menguntungkan dan layak untuk dilaksanakan.

Tabel 5

IRR (Internal Rate of Return)

\begin{tabular}{|c|c|}
\hline Tahun & Laba Rugi \\
\hline 2021 & $-72,518,750$ \\
\hline 2022 & $-1,243,125$ \\
\hline 2023 & $78,692,875$ \\
\hline 2024 & $159,667,163$ \\
\hline 2025 & $243,952,004$ \\
\hline Investasi Awal & $348,100,000$ \\
\hline Nilai IRR & $\mathbf{8 1 \%}$ \\
\hline
\end{tabular}




\section{KESIMPULAN}

Perencanaan keuangan yang telah menunjukan bahwa bisnis ini akan memberikan profit bagi dan layak untuk direalisasikan. Analisa keuangan tersebut terdiri dari Payback Period yang menunjukan bahwa akan Break Even Point dalam jangka waktu 2 tahun 3 bulan, nilai NPV dengan nilai Rp. 291,120,221.5,- atau lebih besar dari nol menunjukan bisnis ini dapat menghasilkan tingkat penghasilan yang melebihi tingkat yang diminta dan nilai IRR sebesar $81 \%$ lebih tinggi dari suku bunga simpanan menunjukan bahwa bisnis ini layak untuk dijalankan.

\section{DAFTAR PUSTAKA}

Barringer Bruce R., \& R. Duane, Ireland. (2012). Entrepreneurship (fourth edition). England : Pearson Education Limited

Chaffey, Dave. (2007). E-business and E-commerce Management ( $3^{\text {rd }}$ ed.) England : Pearson Education Limited.

Gitman, Lawrence J. (2009). Principles of Managerial Finance (twelfth edition). United States : Pearson Education, inc.

Gumbiro, Yudhi B. (2018). Pemanfaatan Instagram Sebagai Media Komunikasi Pemasaran Online Page Down Cloth Maker. Diambil dari http://eprints.ums.ac.id/61512/3/NASKAH\%20PUBLIKASI\%20118.pdf

Hisrich, Robert., Michael P. Peters, dkk. (2008). Entrepreneurship (seventh edition). Singapore : Mc Graw-Hill Companies, inc.

Kusuma, Wahyunanda P. (2019). "Facebook Jadi Medsos Paling Digemari di Indonesia". Diambil $\quad 05 \quad$ Februari 2019, dari https://tekno.kompas.com/read/2019/02/05/11080097/facebook-jadi-medsos-paling digemaridi-indonesia?page $=$ all

Kusuma, Wahyunanda P. (2018). "Riset Ungkap Pola Pemakaian Medsos Orang Indonesia". Diambil 01 Maret 2018, dari https://tekno.kompas.com/read/2018/03/01/10340027/risetungkap-pola-pemakaian-medsos-orang-indonesia

Kotler, Philip., \& Gary, Armstrong. (2018). Principles of Marketing (seventeenth edition). United Kingdom : Pearson Education Limited.

Kotler, Philip., \& Gary, Armstrong. (2012). Principles of Marketing (fourteenth). England : Pearson Education Limited.

Kotler, Philip., \& Gary, Armstrong. (2009). Principles of Marketing a Global Perspective. Singapore : Pearson Education South Asia pte Ltd.

Kotler, Philip., \& Gary, Armstrong. (2008). Principles of Marketing (12 ${ }^{\text {th }}$ ed.). Upper Saddle River, New Jersey : Pearson Education, inc.

Robbins, Stephen P., \& Mary, Coulter. (2016). Manajemen (edisi 13). Jakarta : Erlangga. 